ROCZNIKI FILOZOFICZNE

Volume LXVIII, issue $2-2020$

DOI: http://dx.doi.org/10.18290/rf20682-4

\title{
MURRAY MILES
}

\section{THE THREE FACES OF THE COGITO: DESCARTES (AND ARISTOTLE) ON KNOWLEDGE OF FIRST PRINCIPLES ${ }^{1}$}

\section{INTRODUCTION}

Among the resemblances between Descartes' and Aristotle's theories of the knowledge of first principles one is, regrettably, more of a hindrance than an aid to philosophical understanding. I refer to the lack of concrete detail regarding the exact nature of the cognitive process involved. While memorable and vivid, images like Descartes" "seeds of truth" implanted in the mind by God (AT 6:64, CSM 1:144; cf. also AT 10:376, CSM 1:18), or Aristotle's band of soldiers regrouping after a rout (APos 100a12-14), are hardly more satisfactory, from a philosophical perspective, than the Platonic myth of the soul's recollection of insights acquired during its pre-natal existence in the realm of the Forms. Instead of what would today be considered a developed epistemological theory, all there is to go on is a trail of more or less important clues strewn at intervals through their respective writings. ${ }^{2}$ As in Aristotle's, so in Descartes' case, therefore, all one can hope to

Murray Miles is a professor in the Department of Philosophy, Brock University in St. Catharines, ON, Canada; address for correspondence: 32 Glenridge Avenue, St. Catharines, Ontario L2R4W6, Canada; email: murray.miles@brocku.ca; https://orcid.org/0000-0002-8473-6191.

${ }^{1}$ References to Descartes' works are to volume and page of the definitive Franco-Latin edition of C. Adam and P. Tannery (Oeuvres de Descartes, 11 vols. Paris, 1897-1913, nouvelle présentation par P. Costabel et B. Rochot, Paris, Vrin/CNRS, 1964-76), followed by volume and page of the now standard English translation by J. Cottingham, R. Stoothoff, D. Murdoch, and (third volume only) A. Kenny. Volumes 1 and 2 are designated "CSM," while volume 3 is abbreviated as "CSMK." Square brackets within quotations indicate interpolations by the author.

${ }^{2}$ Cf. Von Fritz (1964, 51): "Es findet sich in den erhaltenen Schriften von Aristoteles überhaupt keine Theorie der Induktion." So too Ross $(1949,48)$ : "Aristotle nowhere offers any theory of the nature of induction"; the "exception" Ross mentions (the treatment of so-called "perfect induction" in $\operatorname{APr}$ 2:23) has nothing to do with "what modern logicians call intuitive induction" (ibid., 49), the only kind in question here. $\operatorname{KAHN}(1981,401)$ remarks that the sequence of stages outlined by Aristotle 
achieve is an inevitably somewhat conjectural rational reconstruction of the theory. Section 3 below attempts such a reconstruction based on a selection of the most important texts. ${ }^{3}$

Notwithstanding the misleading use of the logical particle ergo, Descartes' far-flung hints are at least sufficient to rule out both an indirect (syllogistic) and a direct logical inference as regards his principle of principles, cogito, ergo sum. Everything points instead to a gradually unfolding direct intuition of the universal in the particular, not unlike that described by Aristotle in the last chapter of the Posterior Analytics. To scientific knowledge (epistēmē) acquired by syllogistic reasoning (apodeiksis) from premises already demonstrated (and ultimately from first principles), Aristotle opposes an unmediated process (epagōgē) by which the intellect (nous) achieves a direct apprehension of the first principles themselves. ${ }^{4}$ While apodeiksis "proceeds from the universal" (APos 81b1) via a middle term to the less universal or particular, or from the "prior in itself" (or "by nature") to the "prior for us" (APos 72b31-32), epagogē advances in the opposite direction: starting "from particulars (to kath' hekaston)" (APos 81b1) given in sense perception (aisthēsis) and united in memory (mnēmē) with other perceptions to form

(first sensation, then memory, then experience, and, finally, rational grasp of the universal) "sounds like pulling rabbits out of a hat." Things not unlike the observations of these Aristotle scholars can be said of Descartes' sporadic remarks on the knowledge of first principles.

Aristotle addresses the topic of intuitive induction, directly or indirectly, in many places, APos 2:19 being the locus classicus. A closely parallel account is found in Met 980a27-981a12. Of nous, as the kind of apprehension appropriate to first principles, Aristotle provides a fuller account in $E N$ 6:6 (=EE 5:6) and a still more detailed picture in An 3:4-8. Descartes' pronouncements on the subject are, in virtually all cases, responses to challenges to the primitiveness of his first principle, cogito, ergo sum, on the part of different readers and interlocutors. Nowhere is there anything that could be considered the locus classicus of the problem.

${ }^{3}$ The materials exploited in the following are Descartes' Replies to two Sets of Objections to the Meditations, his Conversation with Burman, The Search After Truth, and the partial list of first principles found in the Principles of Philosophy. Cf. MiLes (1999, Part 3) for a fuller discussion which employs all relevant sources. In section 3 that earlier interpretation is not just repeated but is taken an important step further.

${ }^{4}$ Cf. APos 2:3, where Aristotle lays it down as a necessary truth (APos 72b20) that not all epistēme can be demonstrated or scientific knowledge. For a compilation of other texts bearing on the question, see Lee $(1935,120)$. Barnes surmises, probably correctly, that "the classic distinction between 'intuitive' and 'demonstrative' knowledge, which is common property to rationalists and empiricists" derives from APos 2:19. Descartes formulates his own version of this distinction in Rule 3 of the Regulae, without, however, acknowledging indebtedness to Aristotle. His familiarity with the Aristotelian distinction seems to be attested by this sentence from the Second set of Replies (AT 7:140, CSM 2:100): "Now awareness (notitia) of first principles is not normally called 'knowledge' (scientia) by dialecticians" (i.e., by those medieval logicians who concern themselves with Aristotle's logical writings, including the Posterior Analytics). 
a single experience (empeiria), it advances to the universal, "the one beside the many, whatever is present in all of them as one and the same" (APos 100a7-8), and thence to even wider universals. Early in the Posterior Analytics, Aristotle describes this process as "exhibiting the universal as implicit in the clearly known particular" (APos 71a8-9). ${ }^{5}$ Such intuitive induction or noetic apprehension of first principles is elsewhere distinguished from other types of induction that likewise proceed either from the particular to the general, or from the species to the genus, but only in an empirical manner. ${ }^{6}$

In roughly parallel fashion, Descartes describes the unmediated apprehension of the strictly universal and necessary relation between thinking and existing as a simplex mentis intuitus (AT 7:140, CSM 2:100). As with Aristotelian epagōgē, moreover, it takes its rise from particulars, though Descartes' starting point is empirical introspection of one's own particular acts of thinking rather than ordinary sense-perception of material things. It culminates, however, like Aristotelian intuitive induction, in an understanding of strictly universal principles or first truths, for example, the universal and necessary principle "Whatever thinks, is." Finally, the process is regarded as distinct from what is now called empirical induction, which likewise proceeds from the particular to the general, but only by generalizing over members of a class. Apart from these notable similarities, however, the differences between Descartes' and Aristotle's respective accounts are either too obvious (for example, the difference in starting point) or too controversial (the precise extent and nature of the universal first principles) for there to be much prospect of shedding light on Aristotle's theory through an examination, however minute, of Descartes' first principle, cogito, ergo sum. The converse prospect is, frankly, even poorer. At most, then, a careful reconstruction of Descartes' theory may shed fresh light on the phenomenon with which philosophers of both an empiricist and rationalist stripe have been at grips at least since Plato's Meno and Phaedo.

Apart from the difference in starting point just mentioned - outer sense perception of particulars or aisthessis, for Aristotle, inner perception or introspection of what is implicit in one's own individual acts of thinking, for Descartes- the two

\footnotetext{
${ }^{5}$ Translations vary. This one (G. R. G. Mure in McKeon $\left.[1966,110]\right)$ is suggestive of the theory (attributed to Descartes in section 3) of "making explicit" the already "implicitly" known universal. For that reason, it will seem unduly "rationalist" to some. Other translations, more evocative of an "empiricist" Aristotle, include: "proving the universal by the method of making the particular case clear" (Heath 1949, 37), "proving the universal through the particular's being clear" (BARNES 1975, 1), "proving the universal from the self-evident nature of the particular" (Tredennick in ARISTOTLE $[1966,25])$. See note 16 below on the absence of anything like the Cartesian implicit-explicit distinction in Aristotle.
}

${ }^{6}$ Cf. Ross $(1949,50)$ for more on the empirical forms of epagōgē. 
theories are at odds (though it is difficult to say exactly how far they diverge) regarding the universals known. It is controversial whether the archai grasped through Aristotelian epagōgē include more than just real definitions expressing the specific natures of the entities belonging to the object-domains of the special sciences. ${ }^{7}$ But Descartes, for his part, is perfectly clear in this regard: among the first principles of the sciences are not just (1) ideas of "true and immutable natures" (AT 7:64, CSM 2:44) such as are described in Aristotelian real definitions, but also (2) the empirical propositions cogito and sum, which are the first items of knowledge having 'existential import', and (3) a host of other propositional "axioms or common notions" having no such import whatever. To these last items belong both the so-called law of contradiction and the causal as well as other metaphysical principles of the "natural light" (see AT 8A:11 and 23-24, CSM 1:199 and 209). Section 2 examines briefly the empirical propositions cogito and sum, which are the two principal 'faces' of Descartes' first principle par excellence. ${ }^{8}$ The same cogito, ergo sum exhibits a third face, however, the already-mentioned non-existential principle of the "natural light," 'Whatever thinks, is'. The bulk of the second section is devoted to this, for it is this less-noticed face of the Carte-

${ }^{7}$ According to BARNes $(1975,260)$, Aristotle has "a persistent tendency to treat definitions as the paradigm - or even the sole - case of propositional principles." That is enough to explain his "vacillating" between "a propositional and conceptual account of the principles" (ibid.) in different parts of the Posterior Analytics. KAHN $(1981,391)$ maintains that if the account of epagoge in APst 2:19 is to be "fully coherent," only first principles "which define the subject matter and provide the basis for explaining the phenomena of geometry, astronomy, or biology" etc. can be in question. These are of two kinds: "(1) [real] definitions, or statements of what $X$ is, and (2) hypotheses or assumptions that $X i$, that is to say, the existence claims corresponding to the primary definitions." It is because "the fundamental definitions of a science presuppose or include the existence claim," writes Kahn, that Aristotle "speaks as if the archai of a science consisted only of definitions" (ibid., 392, n. 8). While recognizing that Aristotle deals only with the formation of universal concepts like "animal" and "man" in the culminating chapter of the Posterior Analytics, Ross considers that, in addition to conceptual, various kinds of propositional archai are known by the process there called induction. He produces $(1949,675)$ a very full list that includes, along with several of Euclid's postulates (cf. ibid., 59), "principles that apply to everything that is, i.e. the law of contradiction and that of excluded middle," but also "principles valid of everything in a particular category, such as the principle (common to all quantities) that the whole is greater than the part and equal to the sum of the parts." In addition to these axiomata or koinai archai there are also theses (theseis) or principles proper to some science alone (adiai archai). These are divided into nominal definitions and "assumptions of the existence of things corresponding to the primary terms of the given science" (ibid., 675).

${ }^{8}$ From a historical perspective, it is little short of stunning that a pair of contingent truths about the existence of particulars should be proposed as the first principles of knowledge. For Aristotle, the first principles par excellence are identical with the universals par excellence, in other words, the "most universal universals" or "categories, which alone cannot be resolved into the elements of genus and differentia" (Ross 1949, 678; cf. also BARNES 1975, 254). 
sian cogito which provides the key for the detailed reconstruction of Descartes' rationalist theory of the foundations of knowledge discussed in section 3. Section 4 replies to three obvious objections to Descartes' foundationalism, while section 5 concludes with a condensed summary.

\section{THE THREE FACES OF THE COGITO}

The first of the three faces of the Cartesian cogito can be called the protocogito. It coincides with the first word of the formula, cogito, ergo sum, that is, with the initial proposition, 'I think' or 'I am (now) thinking'. This proposition is only absolutely certain as long as it is understood to assert the existence of a now-actually-occurring mental act, or of a sequence of such acts or states so brief as to be before the mind's reflexive gaze all at once, in the same temporally extended 'now'. ${ }^{9}$ Or, to put the same point negatively, cogito becomes uncertain the moment memory must be relied on to recall what was formerly, but is now no longer, immediately present to self-consciousness. It also becomes uncertain, however, as soon as the immediately evident or "clearly and distinctly perceived" intentional relatedness of acts of thinking to something thought of is mistaken for a real relation of an existing effect or copy in the mind to its cause or original outside the mind. This latter is the most common way in which clearly and distinctly perceived ideas or thoughts become confused (or materially false), thus leading to (formally) false judgments about the existence and/or properties of extra-mental entities. As long as cogito only asserts the existence of acts now actually taking place within the thinking subject's mind, there is no possibility of material falsity, and hence none of formal falsity or error either. ${ }^{10}$

When they speak of the Cartesian cogito, it is rarely of (i) this proto-cogito that scholars are speaking; in the vast majority of cases a tandem of propositions is meant, cogito and sum, joined by the logical particle ergo. This may therefore be

${ }^{9}$ Burman gives Descartes occasion to remark that "it is false that thought occurs instantaneously; for all my acts take up time, and I can be said to be continuing and carrying on with the same thought during a period of time" (AT 5:148, CSMK 335).

${ }^{10}$ Cf. AT 7:233, CSM 2:163: "the falsity to be found in a judgment can only be formal." By contrast, that found in ideas can only be material. Cf. ibid: "as far as ideas are concerned, provided they are considered solely in themselves and I do not refer them to anything else [in my judgments], they cannot strictly speaking be false" (emphasis added). In other words, they cannot be formally false. The distinction of formal from material truth and falsity is discussed at AT 7:43ff. and 232, CSM 2:30-31 and 162ff. On "the perplexing concept of material falsity" (WILSON 1978, 100), see Wells (1984), Normore (1986), and MenN (1995, 198ff) for some of the scholastic background, as well as GewirTh (1968, section 4), Ashworth (1972, 94), and Wilson's later analysis (1990). 
called (ii) the cogito proper. To the direct and infallible insight into the existence of now-actually-occurring ideas, thoughts, or mental states (the proto-cogito), the cogito proper adds the conclusion, sum. The sum asserts the existence of a relatively permanent substance or "thinking thing" (res sive substantia cogitans), while the particle ergo that introduces it makes it clear that this conclusion is reached by some sort of reasoning process or inference; for the existence of a relatively permanent thinking substance that remains numerically identical through the changes in its accidents is not something that can ever be perceived inwardly with the same immediacy and certainty with which the existence of individual states or accidents is perceived from moment to moment. It is rather inferred, and the chief focus of scholarly controversy concerning the cogito proper has been the exact nature of the inferential process indicated by the ergo. That will be the focus of the following section as well.

Third and finally, there is what may be called (iii) the universal cogito, 'Whatever thinks, is or exists.' Descartes formulates it initially in the Principles as "it is impossible that that which thinks should not exist" (AT 8A:8, CSM 1:196). He then reformulates the universal cogito with explicit reference to time or the now implicit in the proto-cogito as: "He who thinks cannot but exist while he thinks" (AT 8A:24, CSM 1:201, emphasis added). Unlike both (i) the proto-cogito and (ii) the cogito proper, (iii) the universal cogito does not assert the contingent existence of anything at all. Accordingly, it figures prominently in a list of "common notions or axioms" (ibid.) that Descartes also calls "eternal truths" (AT 8A:24, CSM 1:209) and principles of "the natural light" of reason (AT 7:52 and 148, CSM 2:35 and 105). Obviously, no such principle, and no truth whatever, not even a derivative one, concerning the "immutable and eternal" (AT 7:64, CSM 2:44) nature of anything possesses the least existential import; their truth therefore does not depend on the actual existence of anything outside the mind. Descartes illustrates this point with reference to the eternal truths of pure mathematics, noting that geometrical theorems about the nature of the triangle - for example, "that its three angles equal two right angles, that its greatest side subtends its greatest angle, and the like"remain eternally true "even if perhaps no such figure exists, or has ever existed anywhere outside my thought" (ibid.). ${ }^{11}$ The same holds for all other eternal truths, some of which describe the real essence of something that exists, like Aristotelian real definitions, while others describe the real essence of something that may or

\footnotetext{
${ }^{11}$ Descartes claims to find within himself "countless" such ideas of "things which even though they may not exist anywhere outside me still cannot be called nothing; for although in a sense they can be thought of at will, they are not my invention but have their own true and immutable natures" (ibid., emphasis added).
} 
may not exist, like Descartes' triangle, and still others the relations between such "true and immutable natures"-between thinking and existing, for example, which is the specific content of (iii) the universal cogito. However, to repeat, no such truth asserts the actual existence of anything outside the mind in rerum natura. ${ }^{12}$

Now if (iii) the universal cogito is not just an eternal, but a first truth or principle of the natural light, it must be both first and a principle in a different sense than (i) the proto-cogito and (ii) the cogito proper. For the latter are first (or first and second, respectively) in the order of knowledge of contingent, empirical propositions whose truth depends on the actual existence of the things that they are about; the universal cogito, by contrast, is one among "countless" (AT 8A:26, CSM 1:209) axioms or common notions that are, collectively, prior to the entire order of contingent or empirical truths. Such necessary truths, along with "countless ideas" (AT 7:65, CSM 2:45) of the "immutable and eternal" natures of things, are therefore absolutely first in the order of knowing. Recalling, in Principles 1:10, that the authors of the Sixth Set of Objections had challenged the status of the cogito, ergo sum as a first truth on the grounds that in order to know that one thinks and exists one must first know what thinking and existence are (cf. AT 7:413, CSM 2:278), Descartes insists that it had not been his intention to "deny that one must first know what thought, existence and certainty are, and that it is impossible that that which thinks should not exist, and so forth" (AT 8A:8, CSM 1:195). It is curious that, along with the "true and immutable nature" of certainty, which was not included along with "thought" and "existence" by the objectors, Descartes here adds the universal cogito to the list of those things that "one must know first." To be sure, this axiom or common notion consists in understanding the relation between the true and immutable natures mentioned, thought and existence; but the main reason for the addition of the universal cogito is that, in answering this objection, Descartes was recalling another. According to Gassendi, the sum cannot be a primitive or first truth precisely because it is the conclusion of a logical syllogism having as its suppressed major the still more primitive truth, "Whatever thinks, exists" (cf. AT 9-1:205, CSM 2:271), and as its minor, the proto-cogito.

Now it is true that, apart from the concept, or "true and immutable nature," of certainty, Descartes adds only (iii) the universal cogito. However, given that the latter figures in the partial list of "axioms or common notions" provided later in the Principles (cf. 1:49), it may be supposed that "one must first know" still other principles, and have still other innate ideas or concepts, in order to arrive at (ii) the cogito proper starting from (i) the proto-cogito. One such principle, without which

\footnotetext{
${ }^{12}$ We may abstract here from the existence of the objects of eternal truths in the mind of God.
} 
obviously nothing can be known to be true and not false, is the law of contradiction. In the list just mentioned, Descartes formulates it in classical Aristotelian fashion: "It is impossible for the same thing to be and not to be at the same time" (AT 8A:24, CSM 1:209). Rather than a formal or logical principle, this suggests a material or metaphysical principle of being, as in Aristotle, a suspicion that is strengthened by the explicit reference to time. Another principle of the natural light, this one unmistakably metaphysical, is the causal principle "something cannot arise from nothing" in the various formulations (including the final, questionable one) given it in the Third Meditation (cf. AT 7:40-41, CSM 2:28). Since all this principle asserts is that if anything exists then there must be a cause of its existence, its truth does not depend on the actual existence of anything, though it is no less metaphysical in Descartes' eyes for having no existential import. Metaphysical in exactly the same sense (and found in the same list) are both the principle "What is done cannot be undone" and the universal form of the cogito, "He who thinks cannot but exist while he thinks." A metaphysical principle that is not included in the list, but is added just three principles later, is "nothingness possesses no attributes, that is to say, no properties or qualities" (AT 8A:25, CSM 1:210). Since it is explicitly labeled a "common notion" (ibid.), it seems reasonable to suppose that this metaphysical principle, too- perhaps above all, as will be argued presently-is among those that "one must know first" in order to know the cogito proper.

Descartes had occasion to clarify the precise sense in which (iii) the universal cogito - and by extension those other non-existential principles just listed - must be understood "first" when Burman (cf. AT 5:146, CSM 3:333) pointed to an apparent inconsistency between a passage from the Second Set of Replies that begins "when we become aware (advertimus) that we are thinking things, this is a primary notion, as it were (prima quaedam notio), which is not derived by means of any syllogism (ex nullo syllogismo)" (AT 7:141, CSM 2:100) and Principles 1:10, where Descartes added the universal cogito to the concepts the authors of the Sixth Set of Objections had declared prior to the cogito, ergo sum. To Burman, that addition suggested a syllogism, or rather an enthymeme with the universal cogito as its suppressed major, which was of course precisely the problem raised by Gassendi. In his reply to Burman, Descartes notes that by adding the universal cogito he had not meant to imply "that I am always expressly and explicitly aware (expresse et explicite cognosco) of its priority, or that I know it before my inference [from (i) the proto-cogito to (ii) the cogito proper]. This is because I am attending only to what I experience within myself (in me experior), for example, 'I am thinking, therefore I exist.' I do not pay attention in the same way to the general notion 'whatever thinks, exists.' As I have explained before, we do not separate out these 
[universal] propositions from the particular instances; rather it is in particular instances that we think of them" (AT 5:147, CSMK 333).

The likely referent of the words "As I have explained before" is the very passage from the Second Replies that follows immediately upon the sentence that occasioned Burman's difficulty. The passage, which disposes handily of Gassendi's objection as well, reads: "When someone says 'I am thinking, therefore I am, or I exist,' he does not deduce existence from thought by means of a syllogism (per syllogismum), but recognizes it as something self-evident by a simple intuition of the mind (simplici mentis intuitu). This is clear from the fact that if he were deducing it by means of a syllogism, he would have to have had previous knowledge of the major premise 'Everything which thinks is, or exists'; yet in fact he learns it from experiencing in his own case (apud se experiatur) that it is impossible that he should think without existing. It is in the nature of our mind to form general propositions out of knowledge of particulars" (AT 7:140-41, CSM 2:100). Here Descartes is exploiting the distinction between "general propositions" and "knowledge of particulars" to illustrate the difference between an indirect logical inference and a direct (simplex) "intuition of the mind." But in the conversation with Burman he goes further. Along with the distinction between particular and universal truths, Descartes introduces another distinction between implicit and explicit knowledge, that is, between knowing something without realizing exactly what one knows or that one knows it, on the one hand, and knowing that very thing while knowing that one knows it. Particular propositions that assert truly the existence of something are the sort of truths that are always attended to first; they are prior in the temporal order of the explicitly known-first with respect to us, as Aristotle was wont to say. Nevertheless, the general concepts employed in such propositions, and the universal principles of which some propositions are particular instances, are prior in themselves or by nature - to use Aristotle's terms once again. For the latter are known beforehand, though only implicitly, without our knowing exactly what they mean or that we know them. Yet because they are implicit in those particular items of knowledge that are the first to be known explicitly, they too are capable of being explicated, that is, of coming to be known explicitly in their turn.

Given the specific objection to which he is responding, Descartes' use of the implicit-explicit dichotomy in his reply to Burman is tailored to the knowledge of principles or propositional truths, and in particular, to (iii) the universal cogito. However, Descartes provides a parallel account of the prior possession of concepts or innate ideas like 'thinking' and 'existence' in the Replies to the Sixth Set of Objections, where he points out that it is through immediate "internal awareness, 
which always precedes reflexive knowledge (cognition illa interna, quae reflexam semper antecedit)" (AT 7:422, CSM 2:285), that the meanings of such concepts are known. The latter, too, are only implicitly understood in the explicit understanding ("reflexive knowledge") of (i) the proto-cogito; and like (iii) the universal cogito, these concepts only come to be objects of explicit awareness, if at all, after the inference process that leads from (i) the proto-cogito to (ii) the cogito proper. In The Search After Truth Descartes adds to the list of such concepts that of doubt (cf. AT 9:523, CSM 2:417), much as he had (apparently gratuitously) added 'certainty' (which is the same thing as 'truth') in Principles 1:10. As will be seen in section 3 , there is nothing gratuitous about either addition.

The foregoing will have to suffice on the third, generally less noticed face of the cogito. It contains positive and negative hints for the understanding of the nature of the reasoning process that leads from (i) the proto-cogito to (ii) the cogito proper. Negatively speaking, the reasoning is not a syllogism, nor yet a direct or immediate logical inference. Positively, it is a simple intuition of the mind that proceeds by stages from the explicitly known particular via the implicitly known universal to the explicitly known universal. With these distinctions in hand, it may be possible to provide an answer to the vexed question of the exact reasoning process involved.

\section{A RECONSTRUCTION}

Prior to the detailed reconstruction of the inference process, two points must be added to the foregoing. To begin with, the operative metaphysical assumptions behind the transition from (i) the proto-cogito to (ii) the cogito proper appear to be two in number. First, those actually occurring acts or modi cogitandi whose existence is affirmed by the proto-cogito have the ontological status of attributes in a broad, non-technical sense of the word that includes all those things variously called modes, properties, qualities, and affections by Descartes. ${ }^{13}$ Secondly, an attribute in this sense is not the sort of thing that can exist in its own right, but only if there exists a different kind of entity for it to be in or be attributed to. Since the attributes whose existence is affirmed in the proto-cogito are all modes of thinking, they can exist only if there exists a substance or thinking thing for them to be attributed to. What this pair of metaphysical assumptions makes appar-

\footnotetext{
${ }^{13}$ The differences among these types of accidents, and the more technical sense in which Descartes uses 'attribute' in contradistinction to 'substance,' on the one hand, and 'mode,' on the other, are unimportant here.
} 
ent is that the reasoning process that proceeds from (i) the proto-cogito to (ii) the cogito proper involves that "common notion" (AT 8A:25, CSM 1:210) or innate principle of the natural light which Descartes formulates succinctly (but ambiguously) as "nothingness possesses no attributes" (ibid.), and which he (mercifully!) disambiguates as follows: "if we perceive the presence of some attribute, we can infer that there must also be present an existing thing or substance to which it may be attributed" (ibid.). From the mere fact that this common notion is involved, it follows, trivially, that the concepts or innate ideas 'attribute' and 'substance' are likewise involved in the transition of the mind from (i) to (ii).

The second preliminary point concerns the precise manner in which these concepts and that common notion function in the reasoning process in question. Here all there is to go on is what Descartes says about the way in which 'thinking', 'existence', 'truth', 'doubt', and the universal cogito are all prior to the cogito proper. From the nature of the priority of (iii) the universal cogito in particular it is clear that "nothingness has no attributes" is not the suppressed major of syllogism. On the contrary, like "Whatever thinks, is," this common notion comes to be known explicitly only after the particular truth expressed in the cogito proper. And yet the transition from (i) the proto-cogito to (ii) the cogito proper is not possible without having at least an implicit understanding of this principle of the natural light beforehand. The way in which the innate ideas 'attribute' and 'substance' and the common notion 'nothingness has no attributes' come to be expressly known in their turn is just a gradual process of making explicit that which was already present to consciousness in an immediate, intuitive manner, yet only implicitly understood in the transition from (i) the proto-cogito to (ii) the cogito proper. As with (iii) the universal cogito, this process or progress of the mind by which 'nothingness has no attributes' and other concepts are known explicitly is just an extension of the very reasoning process that leads from (i) the proto-cogito, via these and other implicitly understood concepts and axioms, to (ii) the cogito proper.

So much for the pair of preliminaries. Now for the detailed—and, as noted at the outset, inevitably somewhat conjectural — reconstruction of Descartes' theory of the process by which the first principles of human knowledge are known. Through introspection and reflection upon the immediate intuition of something actually existing in the mind, there gradually emerges an explicit or clear and distinct understanding of what thinking is, what existence is, and of the fact that the proto-cogito is true, not just beyond a reasonable doubt, but beyond the rational possibility of a doubt. ${ }^{14}$ Since this is just the difference between perceiving

\footnotetext{
${ }^{14}$ Although that whose denial involves contradiction is clearly beyond the rational possibility of a doubt, this maximal degree of certainty is not confined to such cases alone. True, Descartes'
} 
something clearly and distinctly and not so perceiving it, to have understood this difference is to have at least begun to understand explicitly for the first time what doubt or uncertainty and what truth or certainty are. (That is why in The Search After Truth Descartes added 'doubt' to the list of innate concepts that included 'thinking', 'existence', and 'truth' or 'certainty'.) In the course of still further reflection, one gradually comes to understand explicitly for the first time the meaning of other innate concepts and the truth of other innate principles. It goes without saying that none of these could be explicitly understood, or even just more explicitly understood, were they not already understood implicitly in the very act of understanding (i) the proto-cogito.

Now, as noted above, among the ideas or concepts rendered clear and distinct through reflection on the proto-cogito are included also the innate ideas of 'attribute' and 'thing' (res or substance), which are just as primitive as the innate concepts of 'thinking', 'existence', 'doubt', and 'certainty'. Just as no more than an implicit understanding of these latter is required for a grasp of the (i) proto-cogito, so only an implicit understanding of 'attribute' and 'thing' or 'substance' is all that is necessary for the transition from (i) the proto-cogito to (ii) the cogito proper. Indeed, having an implicit understanding of the latter together with 'existence' and 'truth' is just what it means to understand implicitly the truth of the principle disambiguated as "if we perceive the presence of some attribute, we can infer

proto-cogito is merely an empirical and contingent proposition asserting "matter of fact and existence" (Hume); although it can be denied without contradiction, what greater evidence could there possibly be in the field of "matter of fact and existence" than that which belongs to the immediate awareness of the existence of one's own mental states? A doubt about the existence of what is immediately present to consciousness would be just as immune to defeat by rational argument as a doubt about the principle of non-contradiction itself (or a doubt about the reliability of reason, such as Descartes is often supposed to have fallen into by requiring a divine Guarantor of the truth of the clearly and distinctly perceived).

At least three things, then, are beyond the "rational possibility of a doubt" in the sense that all possibility of rational discourse is at an end the moment such a doubt is permitted. First, as Aristotle showed (Met 4:4), there are is the law of contradiction. Deny it (or any of its valid logical transformations, e.g. the law of excluded middle) and, quite literally, "anything goes" (as Leibniz showed, since by taking for granted the truth of any proposition and its contradictory, the truth of any other proposition and its contradictory can be demonstrated). And if anything goes, then rational discourse is impossible. Second, if one doubts the reliability of one's own reason there is simply no possibility of every reliably reasoning one's way out of doubt. This was Hume's point $(1990,181)$ in pronouncing "the Cartesian doubt... incurable." And if "nothing goes," then once again all rational discourse is at an end. Third and finally, if one doubts something as certain as the proto-cogito, then "nothing goes" in the more limited sense that there could never be an adequate reason for accepting any proposition about "matter of fact and existence." For since nothing could be as certain, let alone more certain, than this existential proposition, all debate about "matter of fact and existence" is immediately rendered futile the moment one doubts or denies it. 
that there must also be present an existing thing or substance to which it may be attributed." Thanks to the understanding of this axiom or common notion, there gradually emerges an explicit insight into the existence of a particular substance (sum) as something that was already, if still only implicitly, co-understood in the explicit understanding of the proto-cogito or the actual existence of an attribute.

On (ii) the cogito proper, as a second existential and hence empirical or contingent truth or first principle in the order of knowing, may follow - if one directs one's attention that way- the non-existential insight into (iii) the universal cogito, 'Whatever thinks, exists,' and into any of the "countless" other non-existential truths of the natural light, explicit knowledge of which depends only on the appropriate occasions (usually provided by experience) for becoming thus aware of them. This includes, of course, the clear and distinct understanding of the axiom or common notion formulated as "nothingness has no attributes." Likewise, it is by reflecting on the existential character of the proto-cogito and cogito proper, that is, on the innate idea of real existence implicit in those propositions, that the causal principle "something cannot come [into existence] from nothing" comes to be explicitly known. That principle then serves in the indirect proofs or logical demonstrations of further truths regarding the existence of things outside the mind - of God's existence, in the first instance, and then of that of a material world. However, the gradual unfolding of a series of immediate insights that precedes and makes possible such logical demonstrations is and remains an intuitive process through and through for Descartes. True, this unfolding consists, as just noted, of a series of intuitions that takes place over the course of a sequence of 'nows' rather than 'all at once' or 'in a flash of insight'. Moreover, the entire process figures among those things that Descartes understands by deduction when he opposes the latter to intuitus in the Rules. ${ }^{15}$ Still, it is precisely because the process is at each stage intuitive that Descartes insists on the fluidity of the boundary between intuition and deduction - fluidity, that is, until such time as reliance on memory breaks the chain of immediate intuitions, thus rendering the reasoning deductive and no longer intuitive (cf. AT 10:370, CSM 1:15). Since this gradually unfolding intuitive process is among the things that Descartes understands by deductio, it stands to reason that it also figures among those he has in mind when he uses the word 'infer' and its cognates as well-for example, when he spells out the content of the common notion "nothingness has no attributes" in the passage cited above ("we can infer that there must also be present..."). While 'inference' in this Pickwickian sense

\footnotetext{
${ }^{15}$ See my entry "Deduction" in the Cambridge Descartes Lexicon (Nolan 2015).
} 
has nothing to do with direct or indirect logical inference, it bears, as noted in the Introduction, a certain family resemblance to Aristotelian epagoge . $^{16}$

The reconstruction of Descartes' theory of the knowledge of first principles is now substantially complete. Before attempting, in the next section, to reply to certain objections to the theory, it will be worth making one last attempt to delve deeper into the detail (without claiming to get to the bottom) of the process that Descartes adumbrates in various places but never spells out as fully as one might wish. To that end, it will be well to consider the unity of the two respects in which the process represents a progress of the mind (an inference in Descartes' loose sense of the term). The process starts from principles that remain obscure and confused as long as they are only implicitly understood as instantiated in concreto in clearly (though not entirely distinctly) perceived particulars; and it advances - at times, even on the basis of just one such clearly perceived particular - to the clear and distinct perception of those very principles in abstracto, that is, apart from the particular or particulars in which they were concretely instantiated as initially understood. The passage from implicit to explicit understanding is thus (1) from obscure and confused to clear and distinct perception and at the same time (2) from a clearly perceived particular instance of a universal truth to a clear and distinct conception of that same universal truth in abstracto. ${ }^{17}$

The background assumption here is the well-known Cartesian (and not just Cartesian) doctrine that, in so far as one thinks at all, one is at least to some degree self-consciously aware of what one is thinking. Otherwise what is thought must be and permanently remain beneath the threshold of consciousness, in which case it is simply, as Kant puts it in the Critique of Pure Reason (B132), "nothing for me." In each act of thinking, moreover, one is self-consciously aware of many things

${ }^{16}$ On Descartes' method of “analysis” (AT 7:155, CSM 2:110) and Aristotelian epagōgē, see MiLES (1999), chap. 20. Despite the similarity that consists in the common direction from the particular to the universal, or, equivalently, from that which is prior with respect to us to that which is prior in itself or by nature (cf. AnPo 72b:29-30), the differences are also striking. To those already noted it should be added that Aristotle makes short work of the idea of innateness (APos 2:19), which figures prominently in Descartes' theory. For another, Aristotle makes no use of an implicit-explicit dichotomy in explaining how consideration of a number of concrete particular instances - or sometimes even just a single instance - can "trigger" the grasp of a universal principle, whereas just this is the very heart of Descartes' theory. On the other hand, Descartes, in one place, equates having implicit knowledge of something with knowing it potentiâ (AT 9:655), reverting to a form of the Aristotelian distinction between potentiality and act.

${ }^{17}$ The conversation with Burman contains the pertinent phrase in abstracto et separata a materia et singularibus (AT 5:146, CSMK 332). 
at the same time, yet without being aware of every item to the same degree. ${ }^{18}$ Depending both on how much one is aware of and on the degree of awareness, a perception is either obscure and confused or clear and distinct. The more individual items one is clearly aware of, and the more clearly one is aware of them, the more distinct is the perception overall, though there is obviously an undefined threshold somewhere below maximal clarity of every single item at which it is legitimate to speak of clear and distinct perception even in the case of sensible ideas. It is quite true that clarity and distinctness often seem to be less a matter of being acutely aware of all that is contained in one's perceptions than of not surreptitiously including in them things that are not there at all, for example, when one includes the existence of a cause or original of sensible ideas that is situated outside the mind. But distinctness is in fact a function of both factors: making clear as much as possible of that which is included in one's perceptions, on the one hand, and including in one's judgments only the clearly perceived, on the other. ${ }^{19}$

Applying these considerations now to Descartes' theory of the knowledge of first principles, one can say that to think at all is to be at least obscurely and confusedly aware of universal concepts and principles, including the axiom "nothingness has no properties" that is instantiated or exemplified concretely in every act of thinking; for to think at all is to be at least implicitly aware that the thoughts of which one is clearly aware are only attributes, and that, qua attributes, they must exist in a thinking substance. Through further reflection, the same universal principle may come to be known clearly and distinctly in the abstract, as the axiom that given "the presence of some attribute" one can infer "an existing thing or substance to which it may be attributed." In becoming thus clearly and distinctly aware of this axiom or common notion in abstracto, one becomes, to repeat, explicitly aware for the first time of the general concepts 'attribute' and 'substance' themselves. And as with these, so also with all other concepts in terms of which such principles of the natural light are formulated. For instance, the universal cogito, 'Whatever thinks, exists', is grasped in abstracto through reflection upon one's own particular acts of thinking as implying the existence of a thinking thing to which they all belong, that is, through reflection upon cogito, ergo sum; and it is so grasped, in its unrestricted universality, not by a process of generalization over members of a class, nor yet all at once, in a mysterious flash of insight, but through a process

${ }^{18} \mathrm{Cf}$. AT 5:148, CSMK 335: "it is just not true that the mind can think of only one thing at a time. It is true that it cannot think of a large number of things at the same time, but it can still think of more than one thing."

${ }^{19}$ For a fuller, text-based exposition of the meaning of "clear" and "distinct," see MiLes (1999, section 7.1). 
of gradually becoming aware of the abstract universal by a process of sustained reflection on what is already implicitly understood to be instantiated in particular acts of thinking.

This progress of the mind from the universal, as implicitly understood in the particular, to the clear and distinct conception of the universal in abstracto is that which confers on axioms the same character of certainty that, initially, only the proto-cogito possessed. Their certainty, however, is only definitively established upon elimination of the "very slight and, so to speak, metaphysical doubt" (AT 7:36, CSM 2:25) that infects all such axioms, in other words the hypothesis of a deceiving God who enjoys confounding human reason by making things that are false seem clearly and distinctly true. Now if the proof by which this hypothesis is eliminated employs even one of these axioms, it is obviously circular, and viciously so. After all, one can no more validate a process like intuitive induction by means of an argument that employs premises known by intuitive induction than one can establish the reliability of inductive strategies through empirical induction from their past success (cf. Hume 1990, 81). But even apart from the introduction of the deceiving God hypothesis that renders axioms or first principles doubtful, there seems to be something circular about the reasoning process itself by which clear and distinct perception of them is achieved. The charge of petitio principii will now be considered along with two other salient objections. ${ }^{20}$

\section{OBJECTIONS AND REPLIES}

The first and most salient of the three objections is that the method by which first the cogito proper and then the universal and necessary axioms or first principles

\footnotetext{
${ }^{20}$ In the Fourth Set of Objections Arnauld asks, without any restriction to axioms in particular, "how the author avoids reasoning in a circle when he says that we are sure that what we clearly and distinctly perceive is true only because God exists" and that "we can be sure that God exists only because we clearly and distinctly perceive this" (AT 7:214, CSM 2:150). This suggests that all clear and distinct perception, even the proto-cogito and the cogito proper, are rendered doubtful by the deceiving God hypothesis. However, a moment's reflection shows that these two principles cannot be rendered doubtful by the deceiving God hypothesis since "I am deceived, I therefore exist" is just a particular value of the variable "I think, therefore I exist." Burman, for his part, focuses attention on the common notions or axioms used in the proofs of God's existence: "It seems there is a circle. For in the Third Meditation the author uses axioms to prove the existence of God, even though he is not yet certain of not being deceived by these" (AT 5:148, CSMK 334). Burman's point is that (as Arnauld put it) "we can be sure that God exists only because we clearly and distinctly perceive this" to follow from clearly and distinctly perceived premises, in particular the causal axiom of both Third Meditation a posteriori proofs. In any case, for present purposes only clearly and distinctly perceived axioms or first principles are relevant to the circularity objection.
} 
of the sciences are rendered just as certain or clear and distinctly known as the proto-cogito itself depends on Descartes' robustly rationalist doctrine of innateness. Yet principles of the "natural light" of reason (e.g., AT 7:38 and 7:52, CSM 2:27 and 2:35) implanted by a veracious God as "seeds of truth" in the human mind are wide open to the charge of obscurum per obscurius. Secondly, as just noted, there is something vaguely circular about a reasoning process by which the mind comes to know, and to know that it knows, the truth of axioms that it already knew, without knowing that it knew them. Even if not viciously circular (the first question to be examined), the attempt to remove the "very slight and, as it were, metaphysical doubt" about these axioms by proving God's existence and veracity does seem to amount to a sort of petitio principii. Finally, Aristotle's theory of the knowledge of first principles has been taxed with sounding like "pulling rabbits out of hats" (see n. 2 above). A focal point of discontent has been Aristotelian nous understood as a "flash" (Ross 1949, 50 ) or "final act of insight" (Lee 1935, 122) through which an "immediate and infallible vision of the real world" (Lesher 1973, $45)$ emerges at the end of the process called epagogee. Dissatisfaction with this interpretation has led to more recent efforts on the part of Lesher (ibid.), Barnes (1975), Burnyeat (1981), Nussbaum (1986), and others to provide readings of the Posterior Analytics more consistent with the fundamentally empiricist outlook they attribute to Aristotle. The third problem, then, is whether or not Descartes' theory is open to a form of the same objection, though clearly not to a similar defense. These difficulties will now be considered in turn.

As for the first objection, all that "innate" in fact means in the context of the theory set out in section 3 is that certain universal and necessary principles are discoverable in all their abstract universality simply by attending to, or reflecting upon, particular acts of thinking in which they are concretely instantiated. For to be strictly universal principles, they must be concretely instantiated in every single act of thinking (as in everything else, if anything else exists); and since, as was pointed out earlier, to think is to be to some degree conscious of all that one thinks, those very principles must be constantly exhibited in concreto before one's reflexive - or rather pre-reflexive - gaze as potential objects of sustained reflective attention. By focusing attention on them as instantiated in particular acts of thinking, one comes to apprehend them clearly and distinctly as abstract truths or principles. But if all that is meant by their being innate is their being both constantly instantiated and thus exhibited in concreto before one's pre-reflexive gaze, there is really not much to baulk at here. All knowledge is acquired, and none literally in-born, though some knowledge, notably that of the cogito proper and of certain abstract first principles lacking existential import, is acquired in 
non-empirical fashion, by direct intellectual apprehension, even if empirical introspection is a necessary precondition of such intellectual insight. The images of a "natural light," burning like a candle in the human mind, or of "seeds of truth," implanted in the soul at the moment of creation by a veracious God, are just so much theological embroidery on a philosophical theory of the human intellectual capacity that can stand on its own without them. Descartes, unfortunately, does nothing to mitigate the unfavorable impression created by his theory of innateness when he remarks that certain true and immutable natures and principles are "so open and so much in harmony with my nature, that on first discovering them it seems that I am not so much learning something new as remembering what I knew before... (AT 7:64, CSM 2:63-64). Still, this unmistakable allusion to the Platonic theory of reminiscence is again just embellishment for the benefit of the picture-loving imagination, and not part of Descartes' core doctrine of innateness.

The remainder of the passage just cited evokes the circularity of the process of knowing first principles: "or it seems like noticing for the first time things which were long present within me although I had never turned my mental gaze on them before" (ibid.). As with the initial objection, it is important to distinguish the cognitive process of knowing first principles from Descartes' attempt to exploit it to show that such knowledge depends on knowledge of the true God. If knowledge of $a$ ('everything that is clearly and distinctly perceived is true') depends on knowledge of $b$ ('God exists and is no deceiver'), while, conversely, knowledge of $b$ depends on knowledge of $a$, then obviously no knowledge of either is possible (on pain of circularity). ${ }^{21}$ There is no circle of the kind, however, where the explicit perception of the truth of an empirical proposition asserting the existence of something, $r$ (sum), depends on the explicit perception of the truth of another empirical proposition asserting the existence of something else, $p$ (cogito), together with an implicit (or obscure and confused) intellectual apprehension of a universal and necessary non-existential proposition $q$ ("where an attribute exists, there must exist a substance to which it can be attributed') that is concretely instantiated in $p$ itself; and where an explicit conception of the universal principle $q$ in abstracto et separato ab singularibus (see n. 17) depends on the explicit conception of $p$ together with the implicit perception of $q$ as instantiated in $p$. If clear and distinct conception of all further non-existential first principles of the same kind as $q$ is acquired in just this way, by making explicit and conceiving in the abstract what is already implicitly understood in concreto in the explicit understanding of $p$ (the proto-cogito), then the process of coming to know first principles indeed loops

${ }^{21}$ Doney $(1955,325)$ formulates the problem in these terms before going on to elaborate his (now discredited) memory solution to the Cartesian Circle. 
back, recursively, to $p$; but the circle is, if anything, a virtuous one. To Descartes, in any case, it seemed that 'going round in a circle' in this way was indispensable if axioms are to become as clearly and distinctly known as (the various values of) cogito itself-failing which, all justification would begin and end with the empirical justification of the proto-cogito.

As it turns out, the defeat of the deceiving God hypothesis is not viciously circular either, and it may be worth digressing for a moment to see why not. To Burman's objection that he "uses axioms to prove the existence of God, even though he is not yet certain of not being deceived about these" (see n. 20), Descartes responded by acknowledging his use of axioms, yet denying their uncertainty. He (the meditator) "knows that he is not deceived" by those axioms, he explains, "since he is actually paying attention to them. And for as long as he does pay attention to them, he is certain that he is not being deceived, and he is compelled to give his assent to them" (AT 5:148, CSMK 334). From this (and numerous other passages) it is plain that now-actually-occurring clear and distinct perception is immune to the doubt occasioned by the deceiving God hypothesis. That hypothesis only gains a certain purchase when, no longer attending to the self-evidence of those axioms constantly instantiated in one's own thinking, one simply remembers having clearly and distinctly perceived them to be true in the past. But why should remembered clear and distinct perception be thus subject to doubt? Lurking in the background here is Descartes' strange theological doctrine of the divine creation of eternal truths: God, having created the axioms in question, could alter them, unbeknownst to anyone, the moment the grounds for their truth are no longer attended to. ${ }^{22}$

The certainty of the clearly and distinctly perceived is what Descartes calls persuasio (AT 3:64, CSMK 147); for there to be scientia (ibid.), however, there must exist a body of propositions that can be reliably known to be true whether or not anyone is actually attending to the grounds of their truth. For this, knowledge of the true God is required. There is obviously nothing circular about using now-actually-occurring clear and distinct perception (a proper sub-set of $a$ ) to prove the existence of a veracious God $(b)$, while using $b$ to establish the truth

\footnotetext{
${ }^{22}$ A valuable confirmation of this approach is found in Principles 1:13 (AT 8A:13, CSM 1:197): "And so the mind will be convinced of the truth of this and similar conclusions [e.g., the three angles of a triangle are equal to two right angles, etc.], so long as it attends to the premises from which it deduced them. But it cannot attend to them all the time; and subsequently, recalling that it is still ignorant as to whether it may have been created with the kind of nature that makes it go wrong even in matters which appear most evident [i.e., most clear and distinct], the mind sees that it has just cause to doubt such conclusions, and that the possession of certain knowledge will not be possible until it has come to know the author of its being [i.e., that God exists and that he is no deceiver]."
} 
of remembered clear and distinct perception (another, non-overlapping sub-set of a). But how, then, can one be certain that God exists and is no deceiver when the grounds of this pair of truths are no longer attended to, but only remembered as something clearly and distinctly perceived in the past? Answer: truths about God's own existence and nature, being the only eternal truths that God himself did not create, are immune to all change, even by him; once clearly and distinctly perceived, they are known to be true at all subsequent times. But all this is again just theological embroidery on what is at bottom a fairly sober theory of the human capacity to know first principles; were it not for Descartes' wish to dazzle by reversing the traditional order of knowing and placing knowledge of God ahead of knowledge of the first principles of the sciences, the troublesome deceiving God hypothesis would not have been dreamt up in the first place. ${ }^{23}$

Rather than obscurum per obscurius or petitio principii the chief threat to Descartes' theory comes from the third objection: "pulling rabbits out of hats." Here there is not much prospect of attenuating the force of the objection by reinterpreting the theory along the lines of the familiar empiricist doctrines of psychological abstraction and inductive generalization. A small step in this direction is made, however, in the austere interpretation of Descartes' nativism suggested above. For what is ultimately grasped in abstracto is observed beforehand in concreto in introspection; it is empirically given in a manner that no more admits of doubt than does the proto-cogito itself. Despite the observational starting point, however, axioms or first principles are not discovered by a process of withholding attention from what is peculiar to each of many individual instances of a certain relation, then reflecting on what is common to them all, and, finally, generalizing the result from the observed to all cases, observed and unobserved. But neither, it is worth repeating, is the knowledge of first principles an utterly mysterious flash of insight, which is presumably the real nub of the "rabbit-out-of-a-hat" objection. On the contrary, what Descartes envisages is a gradual process of recurring, with ever greater efforts of attention, to the concrete particular acts of thinking in which the necessary relations expressed in certain axioms are obscurely and confusedly exemplified. In replying to the second objection, this recursive process was described as a virtuous circle without which it is impossible to advance with perfect certainty from (a) the knowledge of our immediately perceived momentary states to (b) the knowledge of ourselves as thinking beings, and finally to (c) knowledge of the existence and nature of beings other than ourselves. Yet the circle is only the brute unexplained 'fact' for which the "rabbit-out-of-a-hat" objection takes

\footnotetext{
${ }^{23}$ See MiLes (1999), chap. 14 for a survey of recent solutions and a more detailed version of the present attempt to absolve Descartes of circular reasoning.
} 
it if there is no hope of shedding further light on the process of "exhibiting the universal as implicit in the clearly known particular" (see n. 5). Assuming there is indeed a reasoning process such as that which both Descartes and Aristotle set over against empirical forms of induction, then while Descartes' theory may only have exposed the proverbial 'tip of the iceberg,' it may be his rather than Aristotle's (or Aquinas') approach to the problem of the knowledge of first principles that lights the way to that philosophical ideal that Strawson $(1966,282)$, in another context, described as "intuitive self-evidence with the sting drawn."

This will have to do as a reply to the third objection. And it is perhaps also the best available response to the more serious objection that has been directed against foundationalism generally. For what seemed "clear and distinct" to Descartes and "necessary" (see n. 4) to Aristotle - that the very possibility of science depends on first principles from which all other knowledge can be demonstrated, but which neither require nor admit of demonstration - is hardly obvious in the light of Quine's critique of this alleged 'dogma' (cf. Quine 1963). While Quine's specific target was the foundationalism of early twentieth-century phenomenalist and physicalist versions of moderate empiricism, his radical empiricist objection obviously strikes at the very heart of the philosophical program with which Descartes' Meditations begin: "to demolish everything completely and start again right from the foundations" (AT 7:17, CSM 2:12). Faced with what has become a formidable 'coherentist' challenge, the best hope for a rationalist defense of foundationalism may be to develop a deeper understanding of the phenomenon-still assuming it is one - of intuitive induction. ${ }^{24}$

\section{SUMMARY AND CONCLUSION}

To sum up briefly and conclude: What is commonly referred to as the Cartesian cogito has three distinct faces, (i) the proto-cogito ("I think"), (ii) the cogito proper ("I think, therefore I am"), and (iii) the universal cogito ("Whatever thinks, is").

${ }^{24}$ Descartes' foundationalist approach to the "structure of empirical knowledge" was notoriously disparaged in the late twentieth century. See, for example, the work so entitled by BonJouR (1985). For a complete about-face and a concerted defense of a type of rationalism and foundationalism strongly reminiscent of Descartes, see BonJour 1998. The Cartesian inspiration is even more evident in BONJOUR 2010, where there are two sorts of foundational truths, empirical truths about now-actually-occurring mental states, on the one hand, and, on the other, axioms or principles. In section 6.7 of the 1998 work, BonJour has intriguing things to say about the instantiation of universals in the human mind as a source of a priori justification. Unfortunately, he develops his ideas in an historical setting that is Aristotelian, and specifically Thomistic, with no attention to the Cartesian theory expounded here. 
The proto-cogito is an empirically known contingent matter of fact, but one that is none the less perfectly certain for being warranted only by immediate introspection. To this very first item in the order of cognitions asserting the existence of something the cogito proper adds a second truth belonging to the same order, and the first to assert the existence of a substance or res. It is warranted by both introspection and a process of reasoning involving the principle of the natural light "nothingness has no attributes." Finally, the universal cogito is an eternal or necessary truth devoid of existential import. Like "nothingness has no attributes" and all other innate principles of the natural light, it is already obscurely and confusedly present to consciousness in the apprehension of the proto-cogito in which it is concretely instantiated. It becomes clearly and distinctly known in abstracto through the very process of reflection on the proto-cogito that led (via the implicit understanding that "nothingness has no attributes") to the explicit knowledge of the cogito proper. It is the same process, moreover, that leads - depending on how one directs one's attention - to the clear and distinct knowledge in abstracto of the universal cogito and "countless" other eternal truths of the same kind, including "nothingness has no attributes."

This, then, is the epistemological theory behind the pleasing but ultimately distorting images ("seeds of truth," "natural light") and the pious, but very nearly fatal attempt to secure pride of place for the knowledge of God within the new order of knowing. It is neither dependent on a fanciful theory of innateness nor viciously circular nor altogether mysterious, though much remains to be done if the intuitive induction by which first principles are known is to be rendered more intelligible than is made by either Aristotle or Descartes himself.

\section{WORKS CITED}

AsHwORTH, Earline J. 1972. "Descartes' Theory of Clear and Distinct Ideas." In Cartesian Studies, edited by Ronald J. Butler. Oxford: Basil Blackwell.

Aristotle. 1949. Prior and Posterior Analytics. Revised text with introduction and commentary by William David Ross. Oxford University Press. Cited as Ross 1949 with page number.

Aristotle. 1966. Posterior Analytics and Topica. Loeb Classical Library 391. Translated by Hugh Tredennick and Edward S. Forster. Harvard University Press and William Heinemann Ltd.

ArISTOTLE. 1975. Aristotle's Posterior Analytics. Translated with notes by Jonathan Barnes. Oxford: Oxford University Press. Cited as Barnes 1975.

BonJour, Laurence. 1985. The Structure of Empirical Knowledge. Cambridge, MA: Harvard University Press.

BonJour, Laurence. 1998. In Defense of Pure Reason. Cambridge: Cambridge University Press.

BonJour, Laurence. 2010. Epistemology. Classical Problems and Contemporary Responses. 2nd ed. Lanham: Rowman \& Littlefield Publishers. 
BURNYEAT. 1981. "Aristotle on Understanding Knowledge." In Aristotle on Science: The Posterior Analytics, edited by Enrico Berti. Padova: Editrice Antenore.

Descartes, René. 1984-91. The Philosophical Writings of Descartes. Translated and edited by John Cottingham, Robert Stoothoff, Dugald Murdoch, and Anthony Kenny. 3 vols. Cambridge: Cambridge University Press.

Doney, Willis. 1955. "The Cartesian Circle." Journal of the History of Ideas 16 (3): 324-38.

Heath, Thomas. 1949. Mathematics in Aristotle. Oxford: Oxford University Press.

Hume, David. 1990. An Enquiry Concerning Human Understanding. La Salle, IL: Open Court.

GewirTh, Alan. 1968. "Clearness and Distinctness in Descartes." In Descartes. A Collection of Critical Essays, edited by Willis Doney. Notre Dame: Notre Dame University Press.

KaHN, Charles H. 1981. "The Role of NOUS in the Cognition of First Principles in Posterior Analytics II 19." In Aristotle on Science: The Posterior Analytics, edited by Enrico Berti. Padova: Editrice Antenore.

LeE, Henry D. 1935. "Geometrical Method and Aristotle's Account of First Principles." The Classical Quarterly 29 (2): 113-24.

Lesher, James H. 1973. "The Meaning of NOUS in the Posterior Analytics." Phronesis 18 (1): 44-68.

McKeon, Richard. 1966. The Basic Works of Aristotle. Edited and with an introduction by Richard McKeon. New York: Random House.

MenN, Stephen. 1995. "The Greatest Stumbling Block: Descartes Denial of Real Qualities.” In Descartes and His Contemporaries: Meditations, Objections, and Replies, edited by Roger Ariew and Marjorie Grene. Chicago: University of Chicago Press.

MiLes, Murray. 1999. Insight and Inference. Descartes's Founding Principle and Modern Philosophy. Toronto and Buffalo: University of Toronto Press.

Nolan, Lawrence, ed. 2015. The Cambridge Descartes Lexicon. New York: Cambridge University Press.

Normore, Calvin. 1986. "Meaning and Objective Being: Descartes and his Sources." In Essays on Descartes' Meditations, edited by Amélie Oksenberg Rorty. Berkeley, CA: University of California Press.

Nussbaum, Martha C. 1986. The Fragility of Goodness. Luck and Ethics in Greek Tragedy and Philosophy. Cambridge: Cambridge University Press.

Quine, Willard van Orman. 1963. "Two Dogmas of Empiricism." In From a Logical Point of View. New York and Evanston: Harper and Row Publishers.

Strawson, P. F. 1966. The Bounds of Sense. An Essay on Kant's Critique of Pure Reason. London: Methuen.

Von Fritz, Kurt. 1964. Die Epagōgē bei Aristoteles. Munich: Verlag der Bayerischen Akademie der Wissenschaften (C.H. Beck Verlagsbuchhandlung).

Wells, Norman J. 2008. "Material Falsity in Descartes, Arnauld, and Suarez. Journal of the History of Philosophy 22 (1): 25-50.

WiLsON, Margaret. 1978. Descartes. London: Routledge.

WiLson, Margaret. 1990. "Descartes on the Representationality of Sensation." In Central Themes in Early Modern Philosophy (essays presented to Jonathan Bennett), edited by Jan A. Cover and Mark Kulstad. Indianapolis, IN: Hackett Publishing Co. 


\title{
THE THREE FACES OF THE COGITO: DESCARTES (AND ARISTOTLE) ON KNOWLEDGE OF FIRST PRINCIPLES
}

\author{
S u m m ary
}

With the systematic aim of clarifying the phenomenon sometimes described as "the intellectual apprehension of first principles," Descartes' first principle par excellence is interpreted before the historical backcloth of Aristotle's Posterior Analytics. To begin with, three "faces" of the cogito are distinguished: (1) the proto-cogito ("I think"), (2) the cogito proper ("I think, therefore I am"), and (3) the cogito principle ("Whatever thinks, is"). There follows a detailed (though inevitably somewhat conjectural) reconstruction of the transition of the mind from (1) via (3) to (2) and back again to (3). What emerges is, surprisingly, a non-circular, non-logical, and ultimately non-mysterious process by which first principles implicitly contained in a complex intuition are gradually rendered explicit (and, if abstract, grasped in their abstract universality). This process bears a striking family resemblance to that intuitive induction ("grasping the universal in the particular") which Aristotle scholars have distinguished from empirical forms of induction.

Keywords: cogito; first principles; intuitive induction; foundationalism; Cartesian Circle.

\section{DESCARTES (I ARYSTOTELES) O POZNANIU PIERWSZYCH ZASAD}

\section{Streszczenie}

W celu systematycznego wyjaśnienia zjawiska określanego niekiedy jako "intelektualne ujęcie pierwszych zasad" przedstawiam interpretację pierwszej zasady Kartezjusza na historycznym tle Analityk wtórych Arystotelesa. Najpierw wyróżniam trzy „oblicza” cogito: (1) proto-cogito („myślę”), (2) właściwe cogito („myślę, więc jestem”) i (3) cogito jako ogólną zasadę („,cokolwiek myśli, jest”). Następnie przedstawiam szczegółową (opartą w pewnej mierze na przypuszczeniach) rekonstrukcję w jaki sposób umysł przechodzi z (1) za pośrednictwem (3) do (2) i z powrotem do (3). Dzięki tej rekonstrukcji, co zaskakujące, otrzymujemy niekolisty, pozalogiczny i ostatecznie wcale nie zagadkowy proces stopniowego uwyraźniania pierwszych zasad zawartych domyślenie w złożonej intuicji, przy czym zasady abstrakcyjne są uchwytywane w ich abstrakcyjnej uniwersalności. Proces ten wykazuje uderzające podobieństwo do intelektualnej indukcji (,wydobywanie treści ogólnej z tego, co jednostkowe"), którą kontynuatorzy Arystotelesa odróżniali od czysto empirycznych form indukcji.

Słowa kluczowe: cogito; pierwsze zasady; intuicja; fundacjonalizm; Kartezjańskie koło. 